Bangladesh J. Bot. 44(3): 423-428, 2015 (September)

\title{
FRESHWATER SEDIMENT DIATOMS (BACILLARIOPHYCEAE) NEWLY RECORDED FROM SIRAJGANJ, BANGLADESH
}

\author{
Khurshid Nahar ${ }^{* 1}$, Abdul Aziz and Moniruzzaman Khondker \\ Department of Botany, University of Dhaka, Dhaka-1000, Bangladesh
}

Key words: Freshwater sediment diatoms, New records, Wetlands, Bangladesh

\begin{abstract}
A total of 11 diatom taxa have been newly recorded and illustrated from the sediments of Joysagar and Sitlai Beel in the district of Sirajganj, Bangladesh. These are Frustulia rhomboides (Ehr.) de Toni, Diploneis smithii (de Breb.) Cl., Stauroneis pygmaea Krieger, S. schroederi Hust., Navicula bicontracta Oestrup, $N$. gottlandica Grun., N. neoventricosa Hust., Caloneis ventricosa (Ehr.) Meister var. minuta (Grun.) Mills, Pinnularia acuminata W. Smith, P. acrosphaeria de Breb. and Nitzschia tryblionella Hantzsch var. subsalina Grun. (syn. Nitzschia tryblionella Hantzsch var. debilis (Arnott) A. Meyer).
\end{abstract}

\section{Introduction}

Benthic algal communities are important primary producers in shallow lakes (Hickman 1971). Anderson (1995) commented that lake sediments can be used as natural documents of perturbation histories i.e. acidification and eutrophication of lakes. Diatom is an effective biological indicator and give background data for natural variability (Dixit et al. 1991).

In Bangladesh, from the diatom families Cymbellaceae and Naviculaceae so far 85 taxa have been reported from different habitats (Ahmed et al. 2009). These include deepwater rice-field flora (Aziz and Ara 2000, Whitton et al. 1988), river plankton (Islam and Haroon 1975), seeping sandstones hill caves (Aziz and Yasmin 1997) and freshwater, saltmarsh and littoral sandy zones of an offshore island namely, Moheshkhali (Islam and Aziz 1979). The seasonality and diversity of sediment diatoms from the two wetlands namely, Joysagar and Sitlai Beel in the district of Sirajganj, northern part of Bangladesh have been studied by Nahar et al. (2010). The present research is a continued effort on sediment diatoms of the same areas and has been found to have many diatoms not reported earlier.

\section{Materials and Methods}

Detailed description of the study sites together with the collection numbers, methods of collecting sediment samples in the field as well as their subsequent processing in the laboratory have been given in Nahar and Khondker (2009) and Nahar et al. (2010). The study sites Joysagar (a huge man made, over 200 year old pond) and Sitlai Beel (natural water body) are situated between $24^{\circ} 28^{\prime} 40^{\prime \prime}-24^{\circ} 28^{\prime} 50^{\prime \prime} \mathrm{E}$ and $89^{\circ} 25^{\prime} 24^{\prime \prime}-89^{\circ} 25^{\prime} 42^{\prime \prime} \mathrm{N}$ in the district of Sirajganj, Bangladesh. During monsoon, the maximum water depth of Joysagar and Sitlai Beel were 2.40 and $2.13 \mathrm{~m}$, respectively.

\section{Results and Discussion}

A total of 11 species of Bacillariophyceae have been identified in the present study as new records for Bangladesh. An illustrated account of those taxa are given and discussed.

\footnotetext{
*Author for correspondence: <drkhnahar@gmail.com>. 'Department of Botany, Jagannath University, Dhaka-1100, Bangladesh.
} 


\section{Order: Naviculalis Family: Naviculaceae \\ Genus: Frustulia Ag.}

1. Frustulia rhomboides (Ehr.) de Toni

(Fig. 1)

(Germain 1981, Pl. 51, Figs 2 - 3; Hustedt 1930, 220, Fig. 324)

Valves rhombic-lanceolate with more or less broadly rounded poles, 47.2 - $165.5 \mu \mathrm{m}$ long and 16-30 $\mu \mathrm{m}$ broad; striae are very uniformly transverse, intersected by longitudinal hyaline lines, 10 - 20 striae in $10 \mu \mathrm{m}$.

Sitlai Beel, Coll. No. 12, 02.05.1997.

2. Diploneis smithii (de Breb.) $\mathrm{Cl}$.

(Fig. 2)

(Germain 1981, Pl. 56, Figs 1 - 3, Hustedt 1930, p. 253, Fig. 402, Lichti-Federovich 1980, 406, Pl. 4, Fig.14)

Valves ellipsoidal with widely rounded poles, side more or less strongly convex $22.3-39.7$ $\mu \mathrm{m}$ long and 15.2 - $23.8 \mu \mathrm{m}$ broad, ribs 5 - 11 in $10 \mu \mathrm{m}$, central nodule less developed.

The valve shape is similar to $D$. ovalis (Hilse) $C$. but the punctations are different near the axial region of Diploneis smithii (de Breb.) Cl.

Sitlai Beel, Coll. No. 08, 25.11.1996.

\section{Genus: Stauroneis Ehr.}

\section{Stauroneis pygmaea Krieger}

(Fig. 3)

(Germain 1981, Pl. 60, Fig. 25; Hustedt 1930, 257, Fig. 40)

Valve sides slightly linear to convex, suddenly narrowed at the poles, capitate, $15-20 \mu \mathrm{m}$ long and 4 - $5 \mu \mathrm{m}$ broad; axial area moderately wide, linear; raphe straight thread like with round central nodule and flat polar nodules; striae are very fine, transverse, difficult to count, appears to have over 20 striae in $10 \mu \mathrm{m}$.

Joysagar, Coll. No. 10, 07.02.1997.

4. S. schroederi Hust.

(Fig. 4 )

(Hustedt 1930, 257, Fig. 410)

Valves narrowly lanceolate, gradually narrowed from the middle towards poles, sharply rounded ends, $60-80 \mu \mathrm{m}$ long and $16-20 \mu \mathrm{m}$ broad; axial area narrow and linear; raphe straight with round polar nodules; striae very fine, parallel but slightly radiating centrally in the mid region, about 20 in $10 \mu \mathrm{m}$.

Joysagar, Coll. No. 10, 07.02.1997.

Genus: Navicula Borey de St-Vincent

5. N. bicontracta Østrup. fa.

(Fig. 5)

(Hustedt 1930, 307, Fig. 549)

Valves linear with two strong pericentral constrictions developing three undulating sides, ends sharply narrowed but long and conical, $45.5-62.0 \mu \mathrm{m}$ long and $9.1-13.0 \mu \mathrm{m}$ broad; axial area linear, very narrow excepting a wider laterally ellipsoidal unornamented area around the central nodule; raphe straight, visible central nodule short rod-like; striae parallel but obliquely placed all along the valve surface, 7 - 9 striae in $10 \mu \mathrm{m}$. 


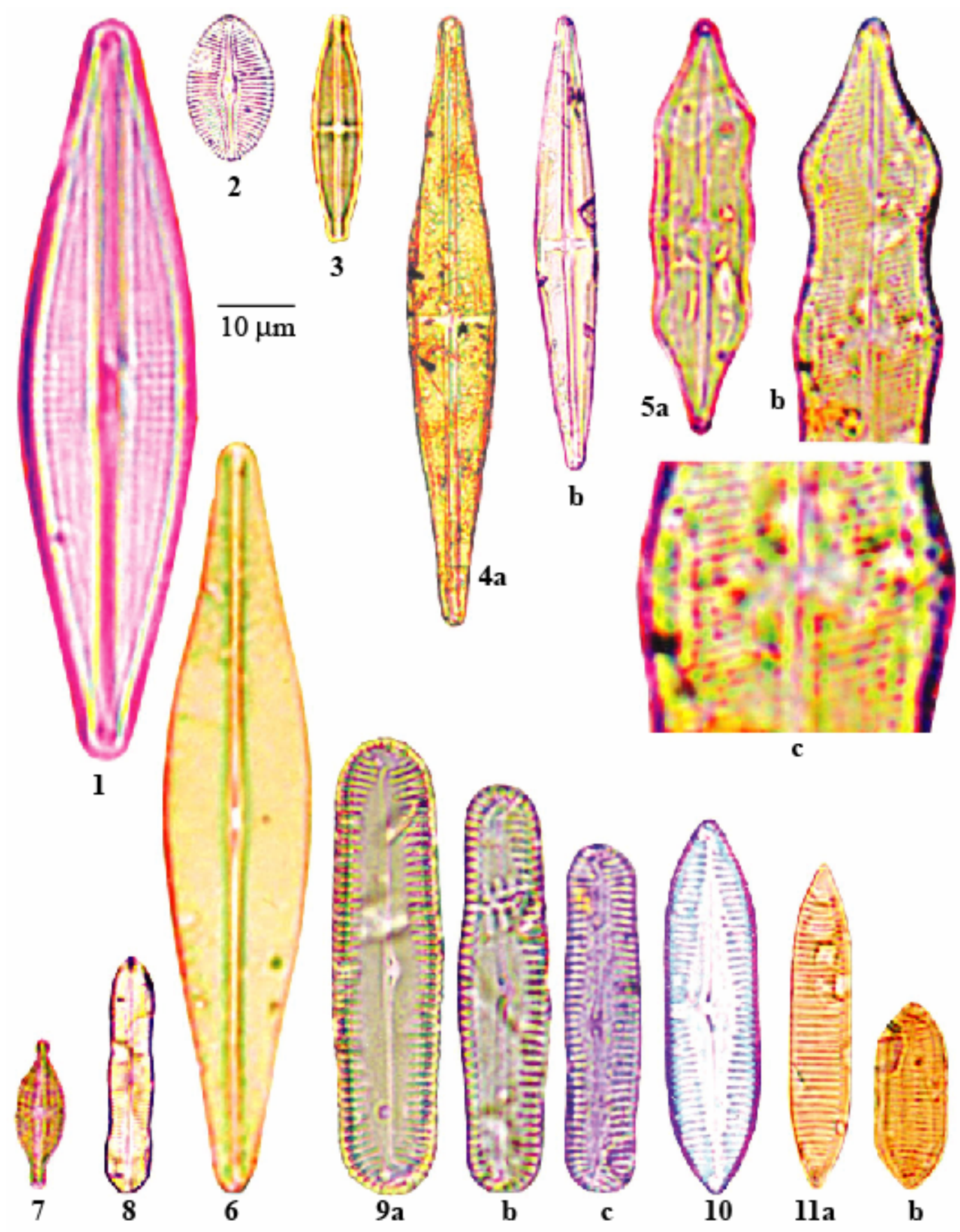

Figs 1-11. 1. Frustulia rhomboides, 2. Diploneis smithii, 3. Stauroneis pygmaea, 4a-b. S. shcroederi, 5a-c. Navicula bicontracta; 6. N. gottlandica; 7. N. neoventricosa; 8. Caloneis ventricosa var. minuta; 9a-c. Pinnularia acrosphaeria, 10. P. acuminata and 11a-b. Nitzschia tryblionella var. subsalina. 
Notes: Parallel but obliquely striae placed all along the valve surface and slightly longer valve ends than the type appears to be unique features in this organism. Further study, needed to confirm its actual identity.

Sitlai Beel, Coll. No. 8, 25.08.1996.

\section{N. gottlandica Grun.}

(Fig. 6)

(Germain 1981, 170 - 71, Pl. 63, Fig. 8; Hustedt 1930, 373, Fig. 690)

Valves medium to broadly lanceolate, with weak but gradually narrowed moderately rounded poles, 47.2 - $165.5 \mu \mathrm{m}$ long and $16-30 \mu \mathrm{m}$ broad; axial area very narrow; raphe visible only beside short rod-like central nodule; striae $>18$ in $10 \mu \mathrm{m}$.

Sitlai Beel, Coll. No. 06, 14.06.1996.

7. Navicula neoventricosa Hust.

(Fig. 7)

(Foged 1976, Pl. 3, Fig.16, Germain 1981, 210, Pl. 80, Figs 1 - 5, Lichti-Federovich 1980, 408, Pl. 5, Fig.16, Wuthrich 1975, Pl. 22, Figs 406)

Valves broadly elliptical with capitates ends, 6.5 - $11.0 \mu \mathrm{m}$ long and $3.5-3.8 \mu \mathrm{m}$ broad; axial area moderately wide, linear up to the poles; raphe thread like and indistinct towards the poles but very distinct on both sides of round central nodule; striae radial, punctuate near the central nodule, 10 - 15 striae in $10 \mu \mathrm{m}$.

Sitlai Beel, Coll. No. 02, 20.09.1995.

\section{Genus: Caloneis $\mathrm{Cl}$.}

8. Caloneis ventricosa (Ehr.) Meister var. minuta (Grun.) Mills

(Fig. 8)

(Germain 1981, 236 - 38, Pl. 87, Fig. 1 - 18, Nakamura-Niiyama 1982, 242, Pl. 6, Fig. 14)

Valves linear with two slight pericentral constrictions developed a gibbous mid-region, ends sharply narrowed in to broadly conical ends, $28.0 \mu \mathrm{m}$ long and $5.6 \mu \mathrm{m}$ broad; raphe straight with undulating axial area; striae parallel to centrally radiating about 15 striae in $10 \mu \mathrm{m}$.

Sitlai Beel, Coll. No. 07, 21.08.1996.

\section{Genus: Pinnularia Ehr.}

9. Pinnularia acrosphaeria de Breb.

(Germain 1981, 256, Pl. 92, Figs 10 - 11, Hustedt 1930, 330, Fig. 610)

(Fig. 9)

Valves linear to slightly swollen in the centre with broadly rounded ends, $27.3-70.0 \mu \mathrm{m}$ long and $6.0-13.0 \mu \mathrm{m}$ broad; axial area wide with fine raphe towards poles but in the centre both the ends curved on one side, striae parallel all through but from poles directed centrally, 7 - 9 striae in $10 \mu \mathrm{m}$.

Sitlai Beel, Coll. No. 07, 21. 08.1996.

10. P. acuminata W. Smith

(Fig. 10)

(syn. P. hemiptera (Kütz.) Cl., Hustedt 1930, 329, Fig. 608)

(Germain 1981, 255, Pl. 92, Figs 1 - 8)

Valves with long linear sides produced in to sharply to moderately narrowed to a narrow conical ends, appearing spindle shape, 41.7 - $50.7 \mu \mathrm{m}$ long and 11.7 - $12.3 \mu \mathrm{m}$ broad; axial area 
narrow at the poles, widest near the central nodule, raphe thread like towards poles but strong centrally with curved ends on one side; costae/ribs parallel, 7 - 9 in $10 \mu \mathrm{m}$. Valves of $P$. pulchra Østrup. (Nahar 2009, p. 160) are close to P. acuminata but costae are radial centrally and more or less parallel at poles.

Sitalai Beel, Coll. No. 2, 20. 09.1995.

Family: Nitzschiaceae; Genus: Nitzschia Hassal

11. Nitzschia tryblionella Hantzsch var. subsalina Grun.

(Figs 11-12)

(syn. Nitzschia tryblionella Hantzsch var. debilis (Arnott) A. Meyer; Germain 1981, 234, Pl. 126, Figs 7 - 9; Hustedt 1930, 399 - 400, Fig. 759, (Germain 1981, 234 - 5, Pl. 126, Figs 1 - 3)

Valves linear and then sharply narrowed in to conical ends, about four times longer than broad with slightly bent ends, $45(17.0$ - 25.0) $\mu \mathrm{m}$ long and 11.0 - $15.0 \mu \mathrm{m}$ broad, 5 - 9 striae in 10 $\mu \mathrm{m}$.

Notes: Nitzschia tryblionella Hantzsch var. debilis (Arnott) A. Meyer described by Germain (1981, 234, Pl. 126, Figs 7 - 9) and Hustedt (1930, 399-400, Fig. 759) is similar to the var. subsalina in terms of valve ends and number of striae in $10 \mu \mathrm{m}$ but much shorter length and wider diameter. Considering Pfitzer's law of diatom cell division the shorter form var. debilis (Arnott) A. Meyer has been kept as a synonym of longer form var. subsalina Grun.

Sitlai Beel, Coll. No. 9, 26.12.1996; Joysagar, Coll. No. 04, 23.4.1996.

\section{Acknowledgements}

The research is a part of Ph.D. thesis submitted by the first author $(\mathrm{KN})$ who obtained a scholarship from the University Grants Commission (UGC) which is duly acknowledged. She is also indebted to the Director General, Secondary and Higher Education under the Ministry of Education, Government of People's Republic of Bangladesh, Dhaka for granting her study leave for carrying out the research.

\section{References}

Ahmed ZU, Khondker M, Begum ZNT, Hassan MA, Kabir SMH, Ahmad M, Ahmed ATA and Rahman AKA (eds) 2009. Encyclopedia of Flora and Fauna of Bangladesh, Vol. 4, Algae. Charophyta to Rhodophyta (Achnanthaceae- Vaucheriaceae). Asiatic Soc. Bangladesh, Dhaka. pp. 543.

Anderson NJ 1995. Using the past to predict the future: Lake sediments and the modeling of the limnologocal disturbance. Int. J. Eco. Mod. Syst. Eco. Elsevier Sci. 78(1-2): 149-172.

Aziz A and Ara M 2000. Diatom taxa from deepwater rice fields at Tangail, Bangladesh. Bangladesh J. Pl. Taxon. 7(1):7-13.

Aziz A and Yasmin N 1997. Algal flora of Madhabkunda waterfall area in Moulvibazar, Bangladesh. II. Green algae and diatoms. Bangladesh J. Bot. 26(2): 177-186.

Dixit SS, Dixit AS and Smol JP 1991. Multivariate environmental inferences based on diatom assemblages from Sudbury (Canada) lakes. Freshwat. Biol. 26: 251-266.

Foged N 1976/81. Diatoms from the Alhambra, Granada, Spain. Nova Hedw. 27: 881-901.

Germain H 1981. Flora Des Diatomees. Diatomtphyceaes. Soc. Nouv. Des. Edin. Boubee. Paris. pp. 444.

Hickman M 1971. Standing crops and primary productivity of the epipelon of two small ponds in North Somerset, U.K. Oecologia 6: 238-253.

Hustedt F 1930. Die Susswasser-Flora Mitteleuropas. Heft. 10. Bacillariophyta (Diatomeae). Verlag Von Gustav Fischer, Jena. pp. 466.

Federovich SL 1980. Diatom flora of Red Snow from Isbjorneo. Carey oer. Greenland. Nova Hedw. 33: 395-431. 
Islam AKMN and Aziz A 1979. Algal flora of Moheshkhali island, Bangladesh. Dacca Univ. Stud. B. 27(2): 105-122.

Nahar K and Khondker M 2009. Addition to the list of freshwater diatoms (Bacillariophyceae) of Bangladesh. 1. Family: Coscinodiscaceae, Fragillariaceae and Eunotiaceae. Taxon. Biodiv. Res. 3: 9-12.

Nahar K, Khondker M and Sultana M 2010. Seasonality and diversity of epipelic diatoms in two wetlands of Bangladesh. Bangladesh J. Bot. 39(1): 29-36.

Nakamura-Niiyama Y 1982. Phytoplankton in lake Abashiri. Environ. Soc. Hokkaido 5(2): 221-281.

Tolonen KM, Harjula LR and Patila AS 1986. Acidification of small lakes in Finland documented by sedimentary diatom and chrysophycean remains. In: Diatom and lake acidity. Smol JP, Davis RB and Merilainen J (Eds.) Dr. Junk Publ. Dordrecht. 171-199.

Whitton BA, Aziz A, Kawecka B and Rother JA 1985. Ecology of deepwater rice-fields in Bangladesh 3. Associated algae and macrophytes. Hydrobiologia 169: 31-42.

Wuthrick M 1975. Résultas des recherches scientifiques au Pare National Suisse. Band 15, 72. Contribution à la connaissance de la flore algologique du Parc National Suisse. Less Diatomées. Nationalpark Museum, Chur. 273-369.

(Manuscript received on 11 September, 2013; revised on 19 August, 2015) 